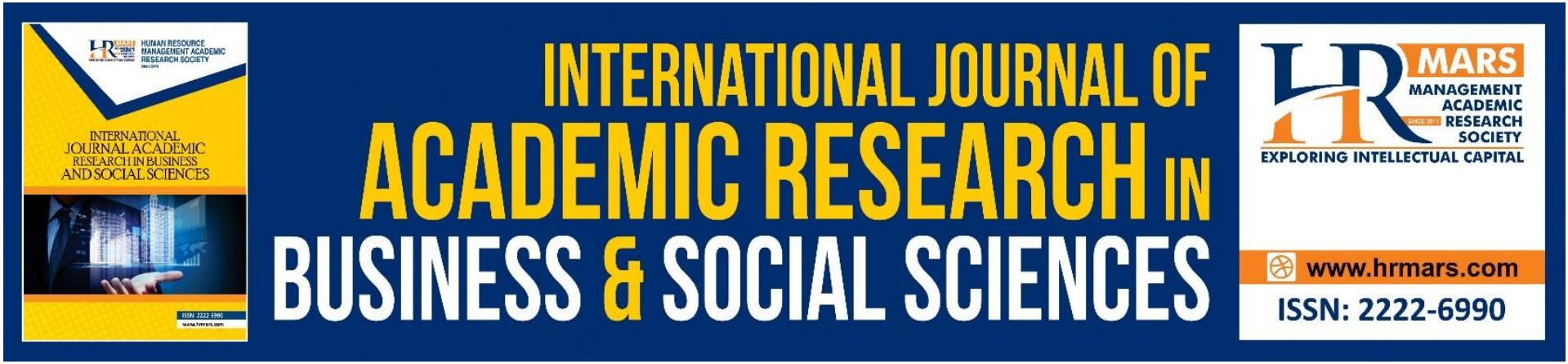

\title{
Communicative Intent of Spoken Discourse by Using Social Stories among Children with Autism Spectrum Disorder
}

\section{Suraya Amirrudin}

To Link this Article: http://dx.doi.org/10.6007/IJARBSS/v11-i3/8582

DOI:10.6007/IJARBSS/v11-i3/8582

Received: 03 February 2021, Revised: 28 February 2021, Accepted: 10 February 2021

Published Online: 19 March 2021

In-Text Citation: (Amirrudin, 2021)

To Cite this Article: Amirrudin, S. (2021). Communicative Intent of Spoken Discourse by Using Social Stories among Children with Autism Spectrum Disorder. International Journal of Academic Research in Business and Social Sciences, 11(3), 820-835.

Copyright: (c) 2021 The Author(s)

Published by Human Resource Management Academic Research Society (www.hrmars.com)

This article is published under the Creative Commons Attribution (CC BY 4.0) license. Anyone may reproduce, distribute, translate and create derivative works of this article (for both commercial and non-commercial purposes), subject to full attribution to the original publication and authors. The full terms of this license may be seen at: http://creativecommons.org/licences/by/4.0/legalcode

Vol. 11, No. 3, 2021, Pg. 820 - 835

Full Terms \& Conditions of access and use can be found at http://hrmars.com/index.php/pages/detail/publication-ethics 


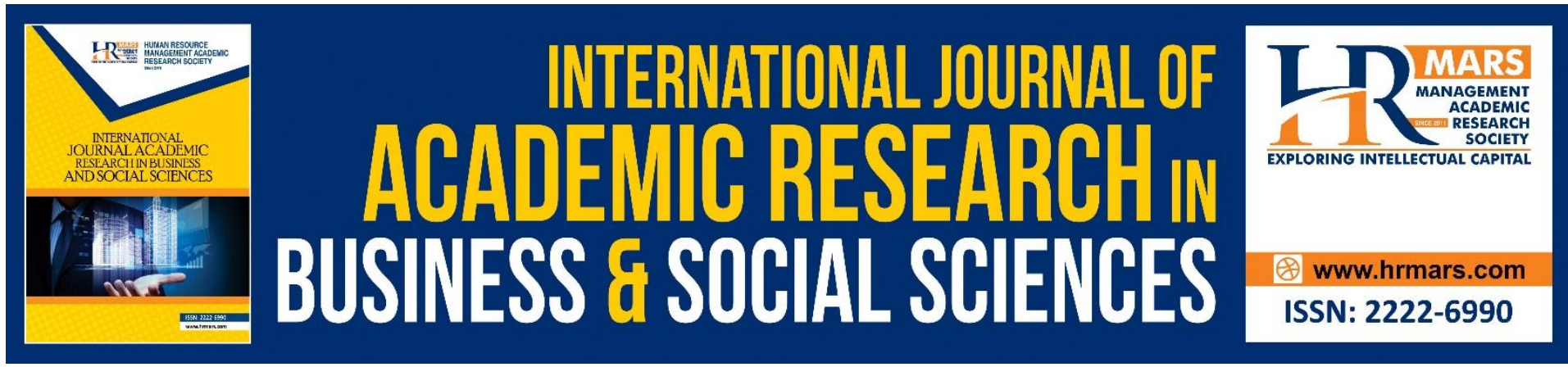

\title{
Communicative Intent of Spoken Discourse by Using Social Stories among Children with Autism Spectrum Disorder
}

\author{
Suraya Amirrudin \\ Infrastructure University Kuala Lumpur
}

\begin{abstract}
It is prevailing that ASD children often seem to have difficulty with social, cognitive and language processes. In this study, the communicative intent of the spoken discourse is examined by using social stories through the identification of the elements of discourse in utterances among ASD children. The current study uses qualitative data to provide details to the research objective, and a case study method design is utilised for the collection and analysis of the data. There are 13 ASD children selected as the sample for the study with four female and nine male children. As for the instruments, the study utilises social stories and semi-structured interview questions. There are three different social stories (Visiting atuk and nenek in Kampung, Being Kind to Animals and Helping My Family) narrated to the respondents. Nevertheless, to explain more about this phenomenon, the current research employs a theory; Discourse Analysis Theory (Normaliza Abd Rahim, 2019). The findings of the study reveal that the 13 respondents display seven communicative intent signals and their spoken utterances subscribe to the three elements (content, context and assumption) mentioned in the discourse theory. The aspects, in theory, have helped the ASD respondents to be able to understand the content and context of the social stories. There is no magic formula for teaching special educational needs students, especially autism.
\end{abstract}

Keywords: Communicative Intent, Spoken Discourse, Social Stories, Asd Children, Discourse Analysis Theory

\section{Introduction}

Special needs children, especially the developmental delays and ASD are not "programmed" to respond to other individuals in their environment, (Jerry, 2020) and so they lack communicative intent. Communicative intent is a critical element that is needed for developing communication skills. In typical children, the desire to communicate wants and desires is innate, and it happens through eye gaze, pointing, even vocalisations. Unlike the ASD children, the deficient of Theory of Mind (ToM) or the ability to understand that other people have thoughts that are separate from their own resulted in them believe that other people are thinking of what they are thinking. They may get angry because significant adults do not know what is happening. The failure to support building communicative intent may also lead to maladaptive or violent behaviour, as the child wants to communicate. Still, 
significantly others have not been attending to the child. Communicative intent can be developed through some ways and to name a few; Picture Exchange Communication System (PECS) and social stories. Once a child has found a means to express communicative intent by pointing, by bringing a picture, or by uttering an approximation, he or she has their foot on the first step toward communication.

\section{Literature Review}

Prizant \& Wetherby (1986) defined communicative intent as the skills to use expressive signals "in a pre-planned manner" until others behaviours are affected. It also has a connection with social relatedness, social cognition, and communicative knowledge. Hence Bates (1979) defined communicative intent as the act of communicating that involves social engagement which means that to engross in intentional communicative behaviour one must understand what social causality is. Communicative intentions are important in interaction as the bases to better understand each other. Van Overwalle (2009) stated that "the human brain is remarkable in its ability to attribute goals and intentions to actions, allowing us to interpret not only what a person is doing but also why they are doing it (general intention)". Social interaction requires humans to recognise subtle cues in behaviour, such as facial expressions and gestures produced with different social intentions. Researchers like Tomasello et al., (2010) have hypothesised that language appeared "phylogenetically and ontogenetically" which means that it comes from the social-cognitive systems explicitly to understand and coordinate intentions through joint action. This mutual system of incorporating language and social cognition permits for the flexible use of gesture and linguistic symbols in the quest of communication.

In discussing communicative intent, Prizant \& Wetherby (1986) created a framework to understand the social-communicative behaviour in autism. According to them, in attributing the communicative intent for non-verbal, pre-verbal or even verbal children, the children's behaviours are the pieces of evidence; alternating eye gaze, persistent signalling, changing the quality of the signal, ritualising the form of the signal within the contexts, awaiting a response from the listener, ending the signal when the goal is met and displaying satisfaction when the goal is attained and at a more advanced level, echolalia and generative language may be used by the children with autism to express their intent. In 2008 Beverly Vicker, in her article "Communicative functions or purposes of communication", she referred to Prizant \& Wetherby's framework with some additional points. On top of vocalisation (sounds, grunts and even unintelligible speech), echolalia and body language, Vicker (2008) mentioned behavioural outputs that include pacing, self-injuries behaviour, sign language, communication display (single picture or words) and communication device (using an electronic device to produce output). In the understanding of language and social impairment of the ASD children studies like Johnston et al., 2019; Loytomaki et al., 2019 and Suraya Amirrudin \& Normaliza Abd Rahim 2019 mentioned about the absence of executive function $(E F)$, and Theory of Mind (ToM) caused the ASD children to manifest the unconventional communicative means. Hence, with functional discrepancies, children with autism often face difficulty in demonstrating communicative intent.

Based on the studies mentioned later in the following paragraphs, there is never an unambiguous relationship between discourse analysis and communicative intent. Discourse or comprehensibility is an important feature for the communicative intent to be seen, influenced and become prominence. These two elements (cohesion and coherent) that 
underpinned discourse have interlinked the semantic property of discourse to communicative intent- the ability to use expressive signals. According to Prizant \& Schuler (1987) in locating the development of communication, there were two major dimensions have been identified: specific intents or purposes for communicating and means (children use to express those intents). In achieving this, close observation can contribute volumes to the communicative intent of a spoken discourse among the ASD children. A variety of observations was hoping to develop a more comprehensive picture of the children's communicative skills. According to Vicker (2008), ASD children would use some means of communication to send messages to other people. Among the means of communication are vocalisation, understandable appropriate speech or echolalia, body language, gestures or even communication display or single picture or words. It is important to know what communicative intention children with ASD are trying to display so new purposes can be taught.

Primarily, deficits in communication are dominant features in ASD, and their absence is evident during social interactions. The investigation of communicative deficits in previous studies was mainly focusing on biases in perceptions, social motivation and cognitive flexibility. Only in recent studies, researchers who studied this matter; communication deficits suggested intervention for treatments. Wadge et al., (2019) studied on ASD children who struggled to bring into line their understanding about communication behaviours with their partner. The researchers said that the children had communicative misalignment, and this explained the reason for them to be weak in their everyday interactions. Nevertheless, these discoveries demonstrate the importance of cognitive and clinical factors in considering social interaction as a communicative alignment challenge and one of the ways in helping it is via communicative strategies. Wadge et al., (2019) corresponded to Stolk et al., (2016) when three years ago they observed the communicative deficits in ASD children and they suggested for human communication "as a solution to a conceptual alignment challenge, organised to predict and monitor mutual understanding". As it can be seen here, more future research is needed to discover options such as embedding social communication interventions into the curriculum.

Having presented all the past studies, communication and communication intent are viewed in discourse analytic approaches as an interactional accomplishment as well as the creation of the interaction between a speaker and a listener. Both interlocutors are responsible for their conversation, any possible interruptions in the flow of the interaction are analysed as the intention to communicate by the listeners. In using the discourse analysis approach in analysing the communicative intent of the spoken discourse among the ASD children, it was the strength of the study to turn their communicative deficits to the conversational context in allowing the identification of their function and relevance of the communicative practices. Furthermore, there were also past studies reporting on children with ASD have difficulties with structural aspects of language such as grammar. In fact, they also have debated that language difficulty will disappear if controlling for the overall language level could be done (Gernsbacher, Morson, \& Grace, 2016; Kjelgaard \& Tager-Flusberg, 2001; Tager-Flusberg, 2015). Meanwhile, there was past literature that discussed the evidence regarding relations between gesture and language in ASD (Manwaring, Stevens, Mowdood, \& Lackey, 2018). Consequently, one avenue to further explore communicative intent in the current study was to use the Discourse Analysis Theory and DAT (2019) from Normaliza Abd Rahim. 
Furthermore, the research objective for the current study was to examine the communicative intent of spoken discourse by using social stories among autism spectrum disorder (ASD) children.

\section{Methodology}

The current study employed the qualitative data to provide the details. A case study design was chosen to allow for a closer approach of the ASD children. Consequently, the researcher has conducted multiple experiments for the research goal. The multiple experiments here indicated the replication of experiments that was done repeatedly to the group of the ASD school children. Furthermore, the case study design here was an empirical enquire that rises out the need to understand the complex phenomenon of the communicative intent of the spoken discourse among ASD children. Therefore, an in-depth data collection involving multiple sources of information like video recordings, the reading of social stories and interview sessions were performed. There were 13 (nine male and four female) ASD students were selected as the subjects for the study.

As for the instruments, social stories are known in research about autism. They are stories written to describe social situations to children with autism. The stories usually are short, individualised and provide support to the unclear social experiences (Gray, 1995). All the three stories were short (in length), containing all the necessary details; description of the situation that is relevant to the social situation (Visit atuk and nenek in kampung, Being kind to animals and Helping my family), personalised social skills (helping, visiting, taking care) and teaching routines to enhance social skills. In measuring the communicative intent, the current study was using two frameworks; Prizant and Wetherby (1986) and Vicker (2008) and in capturing the spoken discourse, the study used Discourse Analysis Theory (2019) by Normaliza Abd Rahim.

\begin{tabular}{|c|c|}
\hline Communicative intent frameworks & \\
\hline Prizant \& Wetherby (1986) & Vicker (2008) \\
\hline $\begin{array}{l}\text { Generative language } \\
\text { (ability of the autistic children in applying } \\
\text { some set of rules to linguistic input in } \\
\text { order to produce a language) }\end{array}$ & $\begin{array}{l}\text { Communication display and uttering } \\
\text { words } \\
\text { (ability to point to something, } \\
\text { respond to show the completion of } \\
\text { verbal routines and utter words) }\end{array}$ \\
\hline $\begin{array}{l}\text { Echolalia } \\
\text { (foundational, and the best language } \\
\text { experiences for a child are whatever } \\
\text { match } \\
\text { his communicative intention }\end{array}$ & $\begin{array}{l}\text { Echolalia } \\
\text { (repetition of others' utterances, } \\
\text { one's own utterances, or audio } \\
\text { media) }\end{array}$ \\
\hline $\begin{array}{l}\text { Alternating eye gaze, persistent signalling } \\
\text { (referential meaning is not inherent in the } \\
\text { communicative act itself } \\
\text { but must be sustained by objects and } \\
\text { events in the environment) }\end{array}$ & $\begin{array}{l}\text { Body language } \\
\text { (facial expression, going limp or rigid } \\
\text { / gestures such as a yes/no } \\
\text { headshake, point, push away, or } \\
\text { made-up gestures) }\end{array}$ \\
\hline
\end{tabular}




\begin{tabular}{|c|c|}
\hline $\begin{array}{l}\text { Ritualising the form of signal within the } \\
\text { contexts } \\
\text { (verbal or non-verbal forms of } \\
\text { communication; or, ways to regulate } \\
\text { human environmental interactions or it } \\
\text { could also be thoughtless actions or habits) }\end{array}$ & $\begin{array}{l}\text { Vocalisation } \\
\text { (sounds, grunts, } \\
\text { speech, shouts) }\end{array}$ \\
\hline $\begin{array}{l}\text { Displaying satisfaction when goal is } \\
\text { attained } \\
\text { (behaviors that may range on a continuum } \\
\text { from automatic and nondeliberate, } \\
\text { through expression of internal states; such } \\
\text { as frustration, boredom, or anxiety, to } \\
\text { intentional communication } \\
\text { protesting) used to } \\
\text { affect others' behaviour) }\end{array}$ & $\begin{array}{l}\text { Questionning } \\
\text { (repeated questions that are directed } \\
\text { with intent to a communicative } \\
\text { partner, and } \\
\text { persist even though a response is } \\
\text { provided. These questions may be } \\
\text { self-generated or consist of echolalia) }\end{array}$ \\
\hline $\begin{array}{l}\text { Awaiting response from listener } \\
\text { (modifying the form of a signal or using an } \\
\text { alternative strategy } \\
\text { that is directed toward another person } \\
\text { after at least one unsuccessfulattempt to } \\
\text { achieve a goal) }\end{array}$ & \\
\hline
\end{tabular}

Table 1: Communicative intent frameworks from Prizant \& Wetherby (1986) and Vicker (2008)

Table 1 above presents the elements of communicative intent from the two communicative intent frameworks- Prizant \& Wetherby (1986) and Vicker (2008). Prizant \& Wetherby (1986) examined the issue of communicative intent with reference to how it may contribute to a greater understanding of the social impairment in autism, and they felt that the acquisition of intentional communication involves synergistic development in social, communicative, and cognitive domains.

\begin{tabular}{lll}
\hline Discourse Analysis Theory (Normaliza Abd Rahim, 2019) & \\
\hline Content & Context & Assumption \\
1. Theme & 1. Grammar & 1. Opinion \\
& 2. Setting & 2. Reference \\
& 3. Emotion & 3. Question
\end{tabular}

Table 2: Discourse Analysis Theory (DAT)

The above Table 2 displays details of DAT. Referring to Normaliza Abd Rahim (2019), the first element of DAT is the content, and this element is analysed through a theme that could be captured from materials like books, texts or even utterances. The theme is the subject that becomes the fundamental of a text, writing, utterances or interaction. The theme can also be the main idea for the discussion. As for the context, it has three sub-elements; grammar, setting and emotion. Grammar focusses on the syntactical and morphological constituent of the words, phrases and sentences. On the other hand, the setting is analysed following the information about location, time and people. As for the emotion, it is analysed when reactions and feelings are shown as the reflection towards a situation. Finally is the assumption. 
Normaliza Abd Rahim (2019) also emphasises that assumption has three sub-headings; opinion, references and question. Primarily, opinion is deliberated from all the sources that surround the discourse, which is the text, utterances and interaction. Reference, on the other hand, is seen as the opportunity that the speaker or writer could have in recalling and bringing in any ideas referring to the matter that is being discussed and lastly is questioned. This subelement is seen as necessary because according to the theorist, it is the nature of the speaker or writer to ask questions for clarification and confirmation on certain things.

\section{Results and Discussion}

\begin{tabular}{ll}
\hline Respondents & Utterances \\
\hline R1 & Love \\
& Peluk atuk nenek (hug atuk and nenek) \\
\hline R2 & Love \\
& Peluk la (hug) \\
\hline R3 & Sayang (Love) \\
\hline R4 & Love \\
& Sayang \\
\hline R5 & Love \\
& Peluk atuk, peluk nenek (hug atuk, hug nenek) \\
\hline R6 & Sayang \\
& Cium tangan atuk dan nenek (kiss atuk and nenek's hands) \\
\hline R7 & Love \\
& Saya cakap I love you. (I tell them I love you) \\
\hline R8 & Love \\
& Peluk nenek, peluk atuk (hug nenek and atuk) \\
\hline R9 & Love \\
& Hug them \\
\hline R10 & Yes...Love sangat (love them so much) \\
& Saya peluk atuk, cikgu...peluk nenek juga. (I hug my atuk and \\
& nenek, teacher) \\
\hline R11 & Yes, love \\
& Say I love you, cium, pegang tangan...buat macam ni... \\
(I say I love you, I kiss and hold their hands. I do like this...)
\end{tabular}

Table 3: Theme: Love 


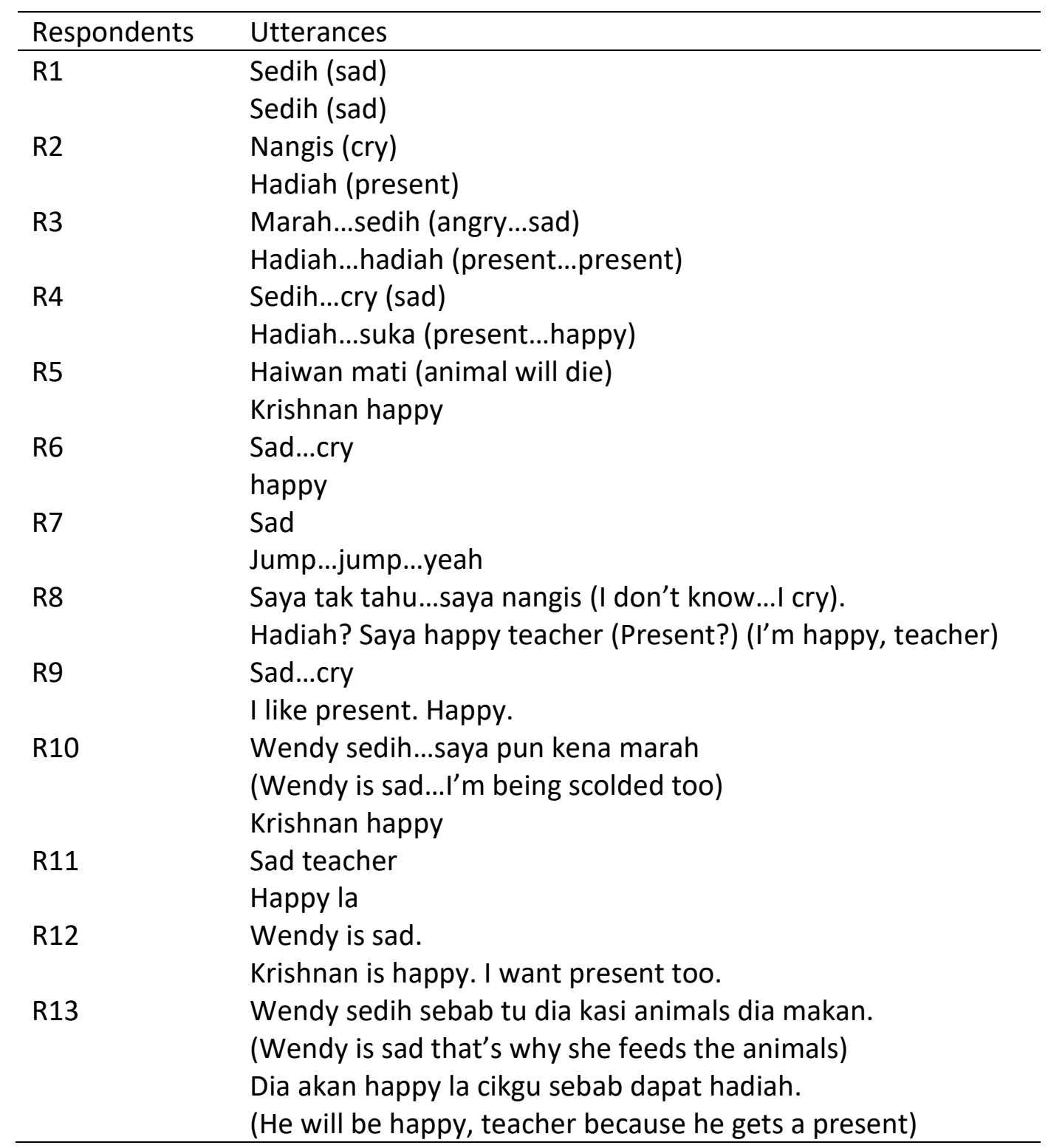

Table 4: Grammar- adjective 


\begin{tabular}{ll}
\hline Respondents & Utterances \\
\hline R1 & Aliff kampung (Aliff is in kampung) \\
& Wendy main dengan animals (Wendy is playing with the \\
R2 & Kamals) \\
R3 & Rumah (at home) \\
R4 & Kampung...rumah nenek (at nenek's house) \\
& river \\
R5 & Rumah \\
R6 & Aliff kat kampung (Aliff is in kampung) \\
& Wendy kat rumah (Wendy is at home) \\
R7 & Aliff kat kampung (Aliff is in kampung) \\
& Wendy kat rumah (Wendy is at home) \\
& Krishnan pun kat rumah. (Krishnan is at home too) \\
R8 & Semua kat rumah mereka (All are at home) \\
R9 & Kampung and house \\
R10 & Di rumah mereka (at their house) \\
R11 & Di rumah mereka (at their house) \\
R12 & Aliff is in kampung and at the river. \\
& Wendy's animals are at home. \\
& Krishnan and his family are staying at home. \\
R13 & Aliff kat kampung (Aliff is in kampung) \\
& Wendy kat rumah (Wendy is at home) \\
& Krishnan pun kat rumah. (Krishnan is at home too) \\
\hline
\end{tabular}

Table 5: location

\begin{tabular}{ll}
\hline Respondents & Utterances \\
\hline R1 & Mandi (bathe) \\
R2 & (no response) \\
R3 & (no response) \\
R4 & Pagi (morning) \\
R5 & Pagi (morning) \\
& Saya mandi pagi (I bathe in the morning) \\
R6 & Saya mandi pagi (I bathe in the morning) \\
R7 & Petang dan malam (evening and night) \\
R8 & Pagi (morning) \\
R9 & Kucing pagi (cat in the morning) \\
& Anjing dia mandi petang (dog is having a bath in the evening) \\
R10 & Kucing hari Isnin (cat is on Monday) \\
& Anjing hari Selasa ke cikgu (dog is on Tuesday right teacher?) \\
R11 & Tengahhari sebab kalau pagi sejuk (it's afternoon, because if \\
& it's in the morning it's cold) \\
R12 & Morning and it cannot be night \\
R13 & Petang. Kalau pagi sejuk (evening...if morning it's cold) \\
\hline Table 6: Time &
\end{tabular}

Table 6: Time 


\begin{tabular}{|c|c|c|}
\hline Respondents & Utterances & Body language \\
\hline R1 & No & $\begin{array}{l}\text { Facial expression changes- } \\
\text { looking worried }\end{array}$ \\
\hline R2 & No & Shake head \\
\hline R3 & (no response) & $\begin{array}{l}\text { Shake head } \\
\text { Eyes were looking at somewhere } \\
\text { else }\end{array}$ \\
\hline R4 & (no response) & Quiet and was looking down \\
\hline R5 & $\begin{array}{l}\text { Tidak (No) } \\
\text { Atuk marah (Atuk is angry) }\end{array}$ & Shake head \\
\hline R6 & $\begin{array}{l}\text { Eggs no } \\
\text { Atuk no }\end{array}$ & Shake head \\
\hline R7 & $\begin{array}{l}\text { No...cannot } \\
\text { Atuk angry }\end{array}$ & Making a frown face \\
\hline R8 & $\begin{array}{l}\text { No } \\
\text { Nanti telur sikit (Eggs will become } \\
\text { lesser) }\end{array}$ & \\
\hline R9 & No & Shake head \\
\hline $\mathrm{R} 10$ & $\begin{array}{l}\text { No. } \\
\text { Marah atuk Aliff. (Aliff's atuk will be } \\
\text { angry) }\end{array}$ & Shake head \\
\hline $\mathrm{R} 11$ & $\begin{array}{l}\text { No...cannot } \\
\text { Atuk marah nanti (Atuk will be angry } \\
\text { later) }\end{array}$ & $\begin{array}{l}\text { Shake head...eyes were looking } \\
\text { at R12 }\end{array}$ \\
\hline $\mathrm{R} 12$ & $\begin{array}{l}\text { If you ask properly, you can take it. } \\
\text { Cannot steal of course. Must ask. }\end{array}$ & Making a frown face \\
\hline R13 & $\begin{array}{l}\text { No tak boleh, cikgu. Kena tanya. } \\
\text { Berdosa... } \\
\text { (No, you cannot teacher. You have } \\
\text { to ask...it's sinful) }\end{array}$ & $\begin{array}{l}\text { Facial expression changes. } \\
\text { Looking serious }\end{array}$ \\
\hline
\end{tabular}

Table 7: Guilt 


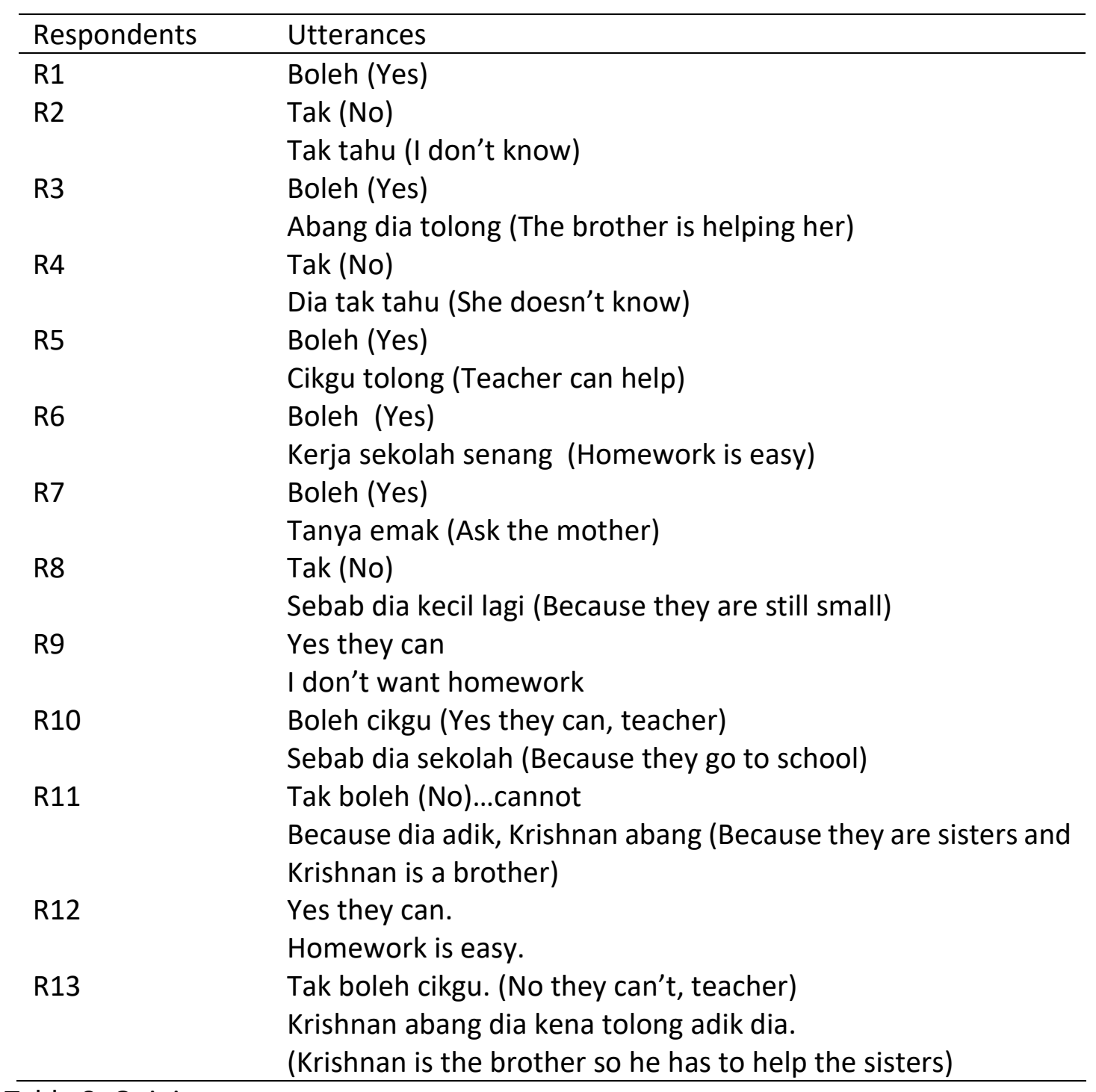

Table 8: Opinion 


\begin{tabular}{ll}
\hline Respondents & Utterances \\
\hline R1 & Tolong ayah (I help my father) \\
R2 & Tolong cuci car (I help him with washing the car) \\
R3 & (hardly made reference) \\
R4 & Aliff suka atuk nenek \\
& Sedih...cry (sad) \\
R5 & Hadiah...suka (present...happy) \\
& Boleh (Yes) \\
R6 & Cikgu tolong (Teacher can help) \\
R7 & Saya mandi pagi (I bathe in the morning) \\
& Saya tolong emak, ayah, semua. (I help my mother, father and \\
R8 & everyone) \\
& No \\
Ranti telur sikit (Eggs will become lesser) & I help my mum with washing...baju, pinggan. (clothes and \\
plates) & I don't want homework \\
& Saya tolong ayah cuci kereta. (I help my father washing his \\
& cars) \\
Boleh cikgu (Yes they can, teacher) & Sebab dia sekolah (Because they go to school) \\
R10 & Saya tolong kakak. (I help my sister) \\
& Kakak pun tolong saya...homework.(My sister helps me too \\
& with my homework) \\
I help Yaya my sister cleaning up her toys. \\
I help others too. \\
Saya banyak tolong ibu. Saya tolong basuh pinggan lepas \\
makan. Tak suka basuh kereta. \\
(I help my mother a lot. I help with washing plates too after \\
eating. I don't like washing the car) \\
\end{tabular}

Table 9: Reference 


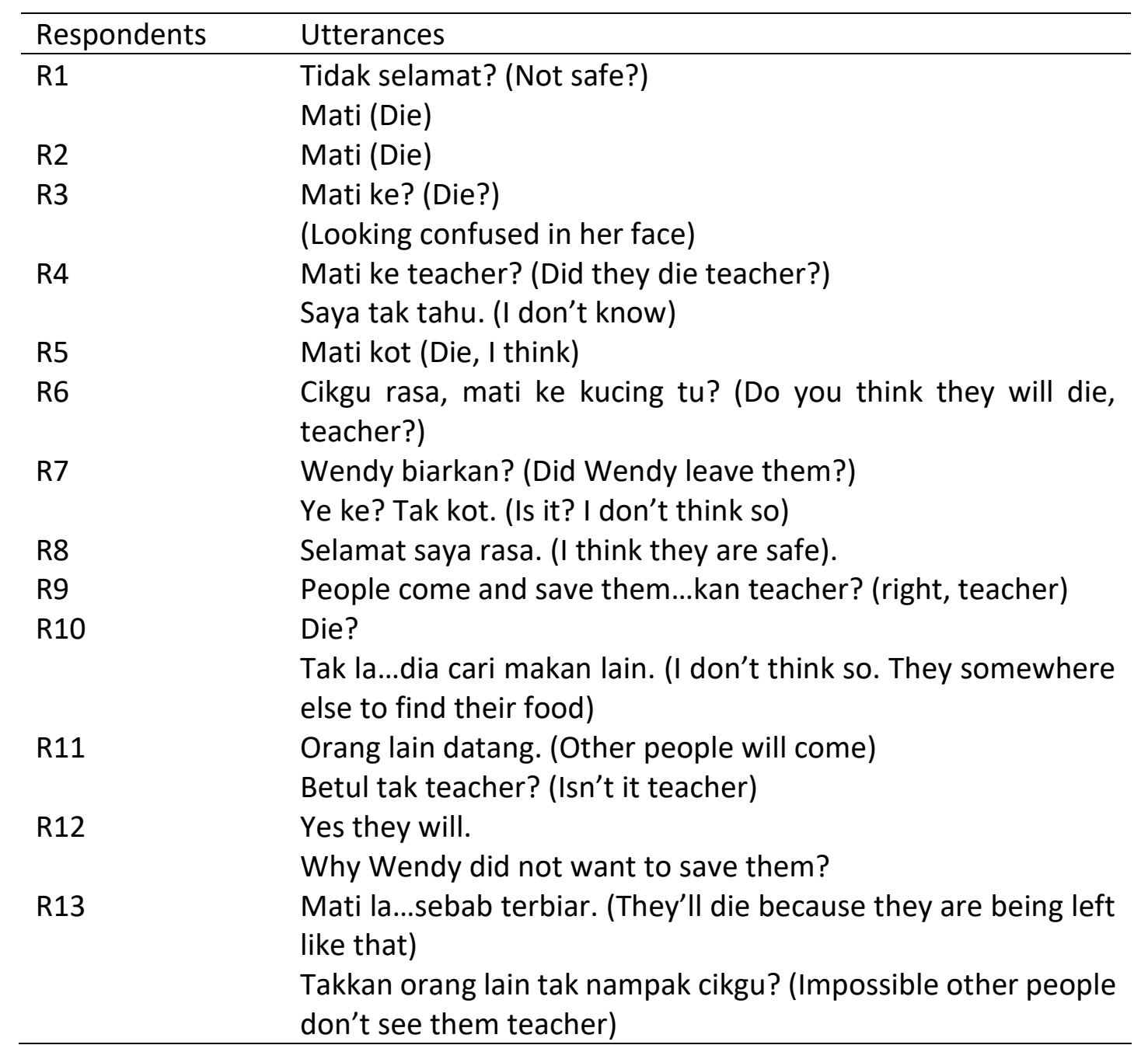

Table 10: Question

By using the Discourse Analysis Theory by Normaliza Abd Rahim (2019), the elements of discourse in utterances among 13 ASD respondents were deliberated from the three main elements; content, context and assumption. The earlier frameworks by Prizant \& Wetherby (1986) and Vicker (2008) were also incorporated to determine the communicative intent of the ASD respondents. Firstly, the themes were taken from the three social stories, love, kind to animals and helping chosen have helped the ASD respondents to take part in the interaction. In getting the whole intention of the conversation from the ASD respondents, vocalisation, intention of uttering words and the words uttered by the ASD respondents were analysed and as the results showed all the 13 ASD respondents could get themselves involved in the discussion through answering the questions. From all the utterances gathered, the content of the social story was understood by the ASD respondents. This was similar to the study conducted by Abd Rahim (2018) onto a group of autism children where she found out that themes in the songs have helped the ASD children participated in the interaction. Furthermore, three parts of speech; adjectives, verbs and pronouns were tested to the ASD respondents. Grammar was said as one of the communicative signals that could be seen from the respondents' language. All these parts of speech seem difficult to them, especially the pronouns. The ASD respondents were seen managed to associate those keywords with their understanding, and further, they could give the right words, although their description was very simple. Indeed, previous research had found that ASD children have difficulties in 
predicting the upcoming content based on the clues that appear in the development of sentences when some researchers mentioned specifically that adjectives and adverbs are complex in its usage even among both ASD and typically developing children (Rao et al., 2016; Dockrell et al., 2019; and Coales et al., 2019). Other than that, children with ASD possess a high level of anxiety towards structural language skills (Rodas et al., 2017; Shahira Rosly, Abd Rahim \& Abdul Halim, 2016). On the other hand, the understanding of location and time were recognised among the ASD respondents. It was shown that the respondents portrayed the ability to understand the location and the concept of time in the conversation. Here, the researcher was also focussing on the echolalia that happened when the ASD respondents were involved in the discussion. Unfortunately, the respondents did not answer based on the time of the clock or days of the week. Nonetheless, the element of setting did help to contribute to obtaining some good utterances too. On the other hand, echolalia was also seen as accompanying the ASD children in this study, and this was found similar to Neely et al., (2016) and Sterponi and Shankey (2014). Furthermore, guilt and sympathy were among emotions that the ASD respondents were tested. As for the communicative intent, their facial expression, eye gaze and other signals were recorded. Overall, they understood the questions and situations given to them, and they managed to come up with their utterances accordingly. The current findings were similar to Tavassolia et al. (2017) and Li et al. (2020). Last but not least, the assumption element that contained opinion, referent and questions as the subs have provided many motivating outcomes too. It was not easy to hear direct views from the respondents, but they could come up with something if the situation and questions posted to them were right. As for the reference, some of the ASD respondents possessed the ability to make them. Some references were in the forms of utterances and some in the forms of body language. Moreover, the ASD respondents asked questions at a low and minimal degree, especially the high-functioning autism children even though many of the questions were not according to what was wanted.

\section{Conclusion}

In using Prizant \& Wetherby (1986) and Vicker (2008) frameworks of communicative intent, the communicative intent signal of 13 ASD children were studied. There were seven communicative intent signals identified in the ASD respondents. Discourse Analysis Theory by Normaliza Abd Rahim (2019) was used to analyse the spoken utterances produced by these ASD children. Overall, the communicative intent showed by the ASD children matched the the three main elements (content, context and assumption) from the theory. First, the whole intention of the conversation from the ASD respondents, vocalisation, intention of uttering words and the words uttered by the ASD respondents have helped the respondents to be able to join in the conversation and interaction, and the content of the social stories was understood better too. Next, the context and ritualising the form of the signal within the contexts was also the communicative intent observed from the ASD children. When the context covered grammar, setting and emotion, the respondents produced spoken utterances that showed them both possessing and lacking the grammar foundations in them. Three grammar features were tested to the respondents; adjectives, verbs and pronouns. As for the setting, it is interesting to note that the respondents did portray the ability to understand location in their utterances. Similarly, the respondents understood the concept of time in the conversation, too but they did not answer the questions based on the time of the clock or days of the week. Somehow, the echolalia signal was observed in these spoken utterances. Turning now to the element of emotion, correspondingly, the ASD respondents 
understood what guilt and sympathy meant, and they revealed both feelings via their body language as well as language. Last but not least, the findings also revealed that the respondents asked questions in providing utterances for the conversation.

The findings concluded that the involved parties can take action and make an effort to help these special educational needs children. There is no magic formula for teaching special educational needs students. Most strategies which could help them are simply good teaching strategies that could be one that might help. The knowledge that is obtained here about Communicative intent, utterances and social stories could be used consistently and consciously to obtain greater effects. Besides that, if the study is to implicate schools and teachers, in educational settings, the principal meditational tool through which learning occurs is language. Therefore, the emphasis should be on language if the learning is to take place among the special educational needs students. Since it is the language that makes learning happens, introducing the special needs students on utterances, and social stories are utmost important.

\section{References}

Gernsbacher, M. A., Morson, E. M., \& Grace, E. J. (2016). Language and speech in autism. Annual Review of Linguistics, 2, 413-425.

Gray, C. A. (1995). Teaching children with autism to "read" social situations. In K.

A. Quill (Ed.), Teaching children with autism: Strategies to enhance communication and socialization (pp. 219-241). Albany, NY: Delmar.

Jerry, W. (2020). Communicative Intent. Retrieved from https://www.thoughtco.com/communicative-intent-building-communication-skills3110826

Johnston, K., Murray, K., Spain, D., Walker, I. \& Russell, A. (2019). Executive Function: Cognition and behaviour in adults with Autism Spectrum Disorders (ASD). Journal of Autism and Developmental Disorders

Kjelgaard, M. M., \& Tager-Flusberg, H. (2001). An investigation of language impairment in autism: Implications for Genetic Subgroups. Language and cognitive processes, 16(2-3), 287-308.

Loytomaki, J., Ohtonen, P., Laakso, M. L., \& Huttunen, K. (2019). The role of linguistic and cognitive factors in emotion recognition difficulties in children with ASD, ADHD or DLD. International Journal of Language and Communication Disorders. Vol. 00 , NO. 0, 1-12

Manwaring, S. S., Stevens, A. L., Mowdood, A., \& Lackey, M. (2018). A scoping review of deictic gesture use in toddlers with or at-risk for autism spectrum disorder. Autism \& Developmental Language Impairments Volume 3: 1-27

Abd Rahim, N. (2019). Kajian Wacana dan Strategi Komunikasi. Teori dan Aplikasi. Penerbit UMT Universiti Malaysia Terengganu

Prizant, B. M., \& Wetherby, A. M. (1986). Communicative Intent: A Framework for Understanding Social-Communicative Behaviour in Autism. American Academy of Child and Adolescent Psychiatry.

Prizant, B. M., \& Schuler, A. L. (1987). Facilitating communication: Theoretical foundations. In D. J. Cohen \& A. M. Donnellan (Eds.), Handbook of autism and pervasive developmental disorders (pp. 289-300). Silver Spring, MD: Winston.

Stolk, A., Verhagen, L., \& Toni, I. (2016). Conceptual alignment: How brains 
achieve mutual understanding. Trends in Cognitive Sciences , 20 (3), 180-191.

Tager-Flusberg, H., Cooper, J., Landa, R., Lord, C., Paul, R., Rice, M., Stoel-

Gammon, C., Wetherby, A. \& Yoder, P. (2015). Defining Spoken Language Benchmarks and Selecting Measures of Expressive Language Development for Young Children With Autism Spectrum Disorders. J Speech Language Hear Research. 2006 Jun; 52(3): 643.

Tomasello, M., Carpenter, M., \& Striano, T. (2010). Role reversal imitation and language in typically developing infants and children with autism. https://doi.org/10.1207/s15327078in0803_4

Vicker, B. (2008). Communicative functions or purposes of communication. The Reporter, 14(1), 13-17.

Wadge, H., Brewer, R., Bird, G., Toni, I. \& Stolk, A. (2019). Communicative misalignment in autism spectrum disorder. Scientific Research NWO (446-14-007) 